\title{
Analysis of Land Use/Land Cover Pattern along the River Benue Channel in Adamawa State, Nigeria
}

\author{
Adefioye Sunday Adewumi \\ Department of Geography, \\ Obafemi Awolowo University, \\ Ile Ife, Nigeria
}

Doi:10.5901/ajis.2012.v2n5p95

Abstract

Uncontrolled human development without adequate consideration for the environment has led to incessant loss of land cover and natural resources such as water in many parts of the world. Consequently, human and environmental challenges of varying magnitude are rapidly emerging. Interestingly, only few efforts are channelled towards the reclamation of the deteriorating land cover pattern and control of future environmental damages, particularly in the developing countries. This study analyses the land use and land cover pattern along the River Benue channel in Adamawa State, Nigeria between 1988 and 2003. Landsat TM satellite image of 1988, Landsat ETM of 2003, and Shuttle Radar Topographic Mission (SRTM) image of the Upper Benue Catchment area were utilize in the study. The study was carried out with a view of classifying the land use and land cover types in the area; examination of land use and land cover changes between 1988 and 2003; generation of contour and elevation maps for the area; and modelling of the terrain of the area using the Digital Terrain Model (DTM). The Upper Benue catchment area was extracted from the Nigeria catchment map, contour map and DTM were also generated in ArcView 3.2 GIS environment. Supervised classification method was adopted to classify the landsat imageries into six (6) classes using ILWIS 3.2 academic GIS software. The implication of the spatial pattern of land use and land cover in the area are accelerated socioeconomic activities, shortage of food, prevalence of drought conditions, paralyzed inland water transportation, desertification and increase in temperature. The study concluded that there is need for a balance between human development, land use planning, and water resource management. Therefore, recommendations were given to ensure sustainable development in the region.

Keywords: Land use/land cover, River Benue, Digital Terrain Model (DTM), GIS /RS, Landsat, Shuttle Radar Topographic Mission (SRTM).

\section{INTRODUCTION}

Land is defined as the earth's surface, including both land and water, and the natural resources in their original states. Land use involves both the manner in which the biophysical attributes of the land are manipulated, and the intent underlying that manipulation - the purpose for which the land is used (Turner et al. 1995).

Uncontrolled human activities has led to significant modification of the natural biodiversity in the world over the years. Consequentially, land use and land covers are changed abruptly without adequate consideration for future developments. There is continuous deterioration from the rich biodiversity. The effects of land uses on the environment ranges from minor land cover changes and soil modification to severe desertification, deforestation, erosion, and river encroachment problems. The incessant need for human development via rapid urbanization has led to a wide spread horizontal development especially in the developing countries. As a consequence, river banks are encroached, vegetal covers are removed, soil properties are modified and many micro to macro ecosystem have gone into extinction. Where these changes are not met with complementing planning and management measures, challenges such as water pollution, high risk to disaster (flood), and unstable food production are unavoidable, particularly in the riverine areas. 
Nigeria is one of the largest countries in Africa $(1,924,000$ square $\mathrm{km})$ and it has the 9th largest population size $(131,859,731)$ in the World (www.census.gov/cgi-bin/ipc/idbrank.pl). The country lies within the latitudes $4^{\circ}$ and $14^{\circ} \mathrm{N}$, and longitudes $3^{\circ}$ and $15^{\circ} \mathrm{E}$. Nigeria shared boundary with Niger, Cameroon, Benin Republic, and the Gulf of Guinea to the north, east, west, and south respectively. The drainage systems in Nigeria consists mainly the Niger-Benue, Chad basins and coastal rivers. The catchment areas in the country are the Niger North, Upper Niger, Upper Benue, Lower Benue, Niger South, Western Littorial, Pasterial Utorial, and the Lake Chad. Water bodies (excluding small reservoirs, ponds, dams, and cultivable wetlands) cover about 149,919square kilometres or 14,991,900hectares of Nigerian land. This constitutes about $15.9 \%$ of total land area of the country.

Theoretically, there is no water problem in Nigeria because the availability seems higher than the present use (Eludoyin A. O., Akinbode M. O., and Ediang O. A., 2007). However, the full potential of drainage systems in the country have not been realized. They have been either under-utilized, neglected or abused. The location of the various rivers have been found, to be spatially beneficial to all the sections of the country, studies have noted some problems using the water resources from these apparent sufficient sources. For instance, Nigeria is classified a water - short country, whose water resource is likely to reduce from 2, 506 cubic meters per year in 1995 to 1, 175 in 2025, if not properly managed. According to the Nigeria Demographic and Health Survey in 2003, 35\% of urban population does not have access to safe drinking water while $70 \%$ of rural population depends mainly on unsafe sources of water such as open wells, rivers, and streams for drinking.

Inadequate land-use planning in areas adjacent to the drainage basin and uncontrolled river encroachment are vital factors adding to the consequences of water challenges and security in the country. The flood plains of the Nigeria river systems are often cultivated without any planning or management practices. Chemicals from the farms are washed into the rivers, hence making them unsuitable for domestic consumptions. The adjacent cultivated soil are loosened thereby causing massive silt-washing into the river system. Wastes were being disposed into the river by the adjoining settlements.

River basin management policies and planning strategies could be used for effective utilization of Nigerian drainage basins for sustainable development. This realization of the importance of adequate water management has probably encouraged the Nigerian government to establish a number of River Basin Development Authorities (RBDAs) (Eludoyin A. O., Akinbode M. O., and Ediang O. A., 2007). The (RBDAs) were charged with the responsibility of a comprehensive water resources (surface and groundwater) development of Nigeria for multipurpose uses.

For a sustainable river basin management policy to be implemented, a corresponding effort must be attained through effective land use planning and management at the adjoining areas around the water channels. Analysis of the land use pattern in the drainage basins using geospatial technology is an approach that would provide reliable information for effective planning and implementation of management policies for both river basins development and land use planning for urban and agricultural development in these areas.

Utilization of satellite imageries and application of Geographic Information Systems (GIS) with its database management, analysis (spatial and non-spatial), modelling and visualization capabilities would ensure the development of frameworks on which both spatial and non-spatial planning could be built upon in the drainage areas. Successful adoption of this approach is suitable and could be applied to six (6) key planning and management areas along the Nigerian drainage basin. These areas include;

1. Land use planning and management around the River channels

2. Water resource management

3. Disaster management (particularly flooding)

4. Inland Fisheries planning

5. Agricultural land use planning (wetland/flood plain cultivation), and

6. Inland water transport planning and management. 
Remote Sensing (RS) and Geographic Information System (GIS) are now providing new tools for advanced ecosystem, land and water management (Abiodun E. O, Olaleye J. B., Dokai N. A., and Odunaiya A. K., 2011). They provide the medium for the integration of both spatial and non-spatial data. GIS and remote sensing have been widely recognized as an effective tool for planning and decision-making tasks (Martin and Howarth, 1989, Treitz, Howarthand Gong, 1992, Trotter, 1991).

Therefore, this study utilizes the tools of Geographic Information System (GIS) and Remote Sensing in the analysis of the land use pattern along the River Benue channel in Adamawa State, Nigeria.

\subsection{Aim}

The aim of this study is to analyse the spatial pattern of land use/land cover along the River Benue channel in Adamawa State, Nigeria.

\subsection{Objectives}

The specific objectives that this study intends to achieve includes;

1. Identification and classification of land use/land cover types along the river Benue channel using LandSat Enhanced Thematic Mapper (ETM) imagery of 1988 and 2003

2. Examination of changes in land use/land cover in the area

3. Generation of contour and elevation maps for the area using the SRTM satellite image of the Upper Benue catchment area.

4. Modelling the terrain of the area using the Digital Terrain Model

\subsection{Study Area}

The study area is located in Adamawa state, within the Upper Benue catchment area.

Adamawa is a state in the Northeastern part of Nigeria and located within latitude $9^{\circ} 11^{\prime} \mathrm{N}$ to $9^{\circ} 20^{\prime} \mathrm{N}$ and longitude $12^{\circ} 23^{\prime} \mathrm{E}$ (Ishaku, 1995). The state was formed on August 27, 1991 from part of the Gongola state with its capital at Yola. Nicknamed as the "Land of Beauty", Adamawa state has twenty-one local government areas, divided into four administrative divisions namely: Adamawa, Ganye, Mubi and Numan.

Adamawa is one of the largest states of Nigeria and occupies a total area of about 36,917square kilometres. It is bordered by the states of Borno to the northwest, Gombe to the west and Taraba to the southwest. Its eastern border also forms the national eastern border with the Federal Republic of Cameroon. The Mandara Mountains lie in the northeastern part of the state along the Cameroon border and the Shebshi Mountains rise to Mount Dimlang $(2,042 \mathrm{~m})$ in the state's southeastern portion. Adamawa State is largely covered by short-grass savanna and is drained westward by the Benue River and its tributaries, including the Gongola, Taraba and Pai rivers (Maitera O. N., 2011).

Adamawa State is multi-ethnic. The inhabitants of the state belong to, among other tribes, Fulani, Bachama, Mbula, Mumuye, Higi, Chamba, Margi (Marghi), Hausa, Kilba, Gude, Lunguda, Yungur, Kanakuru and Bata tribes. All the tribes in the region except the Hausa traders are primarily engaged in crop farming and livestock herding (cattle, goats, sheep), but fishing is predominant along the riverbanks. Peanuts (groundnuts), cotton, sorghum, millet, rice, and corn (maize) are the main crops (Maitera O. N., 2011). This is reflected by the two predominant vegetation zones in the region - the Sub-Sudan and North Guinea Savannah Zone. The state has networks of roads linking all parts of the country. Figures 1 and 2 shows the location of Adamawa State on the Nigerian Map and the local government areas in the state respectively. 


\section{River Benue}

Adamawa is one of the five (5) states through which the River Benue passed through. Other states are Taraba, Nassarawa, Benue, and Kogi. River Benue is the longest tributary of River Niger; being about 1,083 km in length. River Benue rises in northern Cameroon as the Bénoué at about $1,340 \mathrm{~m}$ and in its first $240 \mathrm{~km}$, it descends more than $600 \mathrm{~m}$ over many falls and rapids, the rest of its course being largely uninterrupted. During flood periods its waters are linked via the Mayo-Kebbi tributary with the Logone, which flows into Lake Chad. Below the Mayo-Kebbi the river is navigable all year by boats drawing less than $0.75 \mathrm{~m}$ and by larger boats for more restricted periods (Encyclopedia Britanica, 2004). A considerable volume of imports (particularly petroleum) is transported by river, and cotton and peanuts (groundnuts) are exported in the same way from the Chad region. Between Yola and Makurdi the Benue is joined by the Gongola and it then flows east and south for about $480 \mathrm{~km}$.

\subsection{Scope of the Study}

The study covers four (4) local government areas in Adamawa state including - Girei, Ifurore, Yobe North and Yobe South. The study covers an area between lat $9^{\mathrm{O}} 30^{\prime} \mathrm{N}$, long $12^{\mathrm{O}} 17^{\prime} \mathrm{E}$, and lat 9 $5^{\mathrm{\prime}} \mathrm{N}$, long $12^{\mathrm{O}} 35^{\prime} \mathrm{E}$.

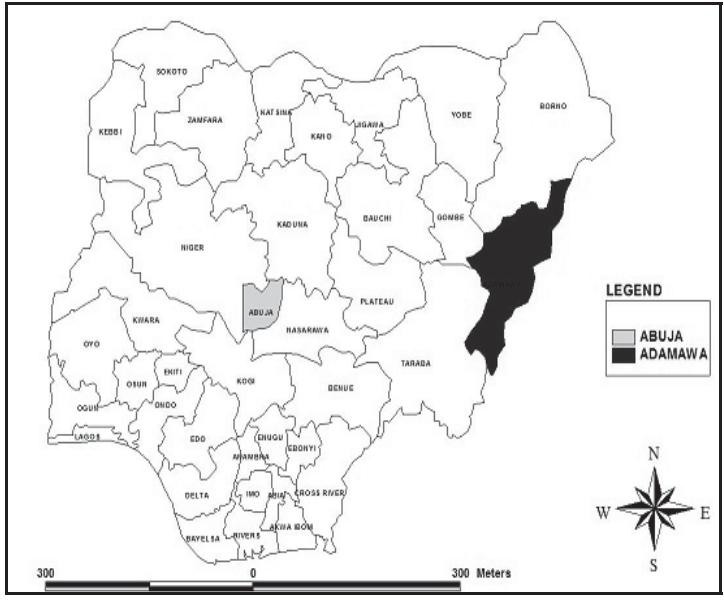

Figure 1: Map of Nigeria Showing Adamawa State

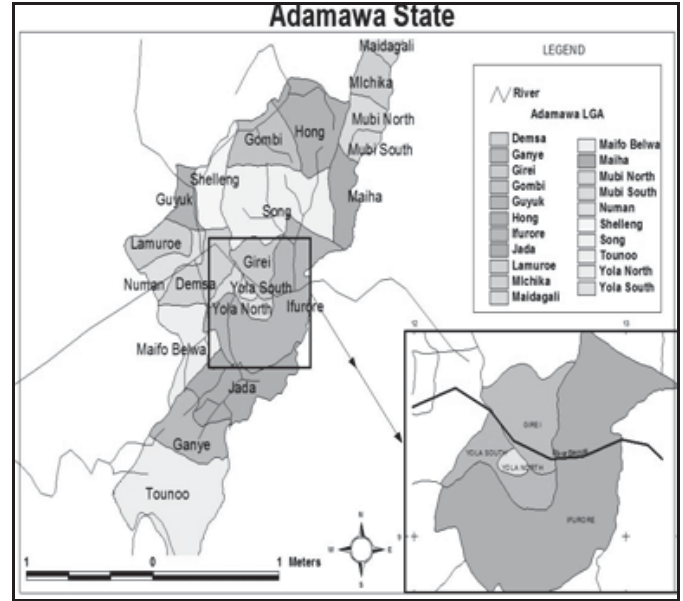

Figure 2: Local Government Areas in Adamawa State

\section{Literature Review}

Several studies have been carried-out over the years in the analysis of land use/land cover patterns and changes, and assessment of the river basins/channels in Nigeria.

Land Use Analysis

Since the beginning of the 19th Century, vast portions of the earth's surface have been modified, whole ecosystems destroyed, and global biomass altered or eliminated (Fellmann et al 2005). The most important of 
the land surface changes in many part of the developing country has been that of man activities, especially grazing, farming, bush burning, wood cutting and other activities such as road construction (Baltimore 1987).

The knowledge about land degradation has become increasingly important as the nations plans to overcome the problems of haphazard, uncontrolled development, deteriorating environmental quality, loss of important wetlands, river encroachment, and loss of fish and wildlife habitat. Landuse data are needed in the analysis of environmental processes and problems that must be understood if living conditions and standards are to be improved or maintained at current levels especially at this population exploding era (Ikusemoran Mayomi, 2009).

One of the prime prerequisites for land degradation is information on the existing landuse patterns and changes in landuse through time. The knowledge about human impacts on landuses such as agricultural, recreational, as well as information on their changing proportions, is needed by legislatures, state and local Government officers to determine better landuse policy, to identify future development on pressure points and areas, and to implement effective plans for regional development (Ikusemoran Mayomi, 2009).

\section{GIS Application in Land Use Analysis}

The ability to forecast land use and land cover change and ultimately to predict the consequence of change will depend on our ability to understand the past, present and future state of land use and land cover change (Oyinloye M. A., Kufoniyi O., 2011). This ability is enabled through the use of multi temporal remote sensing data and or aerial photographs which provides valuable information for natural resources like land, water, forests, urban areas and infrastructure facilities such as road network, river network etc (National Research Council, 2001). Remote Sensing/Geographic Information System (GIS) have been applied to landuse and landcover change analysis, detection and monitoring all over the world. Mattikalli, (1995), applied Remote Sensing and GIS to the land use of the River Glen catchments in England by acquiring data from 1931 to 1989 . His work revealed that much of the grassland changed to arable land during the study.

Similarly, Zhi-Yong Yin, et al (2005) used image processing and analysis in a GIS environment to assess spatial change in urban land use patterns and population distribution. The unsupervised classification was used to classify the images into land use classes. Census polygon was constructed into various sets of units using census data in a GIS, and then comparison made with the classified image population in surface areas. In his studies carried out by 2004 in Shaoxing City in China, Zhi-Yong Yin uses satellite imageries for the year 1984, 1997, and 2000. One of the goals of the study was to produce a landuse map of Shaoxing city and its surroundings, the result shows that there are undoubtedly a lot of changes that occurred between 1984 and 1997 when compared with those of 2000, due to the sufficient time gap. From the study, it was observed that residential area development was mainly at the expense of agricultural land use.

\section{River Basin/River Channel Assessment}

Both natural processes and anthropogenic interferences influence the quality and quantity of river water. The anthropogenic constitutes one of the major causes of environmental problems that alter the hydrochemistry in our river systems. Rivers are highly heterogeneous at spatial as well as temporal scales. Variation in the quality and quantity of River water is widely studied across the globe (Ishaq S. E., Agada P. O., and Rufus S. A., 2012). Riedel et al. (2000), examined the spatio-temporal variation in trace elements in Patuxent River, Maryland. Gupta and Chakrapani (2005) also studied temporal and spatial variations in water flow and sediment load in Narmada River Basin, India. Temporal and spatial variation of nutrient levels in the Nemunas River (Lithuania and Belarus) has been reported (Sileika A., et al (2006)). Multivariate statistical techniques for the evaluation of spatial and temporal water quality of the Mahanadi River - estuarine system, was reported in India (S. K. Sundaray, et al). 


\section{Methodology}

Data Source

The primary data used for this study is the Enhanced Thematic Mapper (+ETM) Landsat Image of Adamawa State, Shuttle Radar Topographic Mission (SRTM) image of the Upper Benue Catchment Areas, Catchment map of Nigeria, and political map of Adamawa state. The Landsat image uses the Universal Transverse Mercator (UTM) projected coordinate system and WGS84 datum in zone 33. It has a spatial resolution of 28.5metres.

Equipment and Software

ITC ILWIS 3.3, ENVI, and ArcView 3.2 GIS software were utilized for image processing, analysis and presentation.

Analysis

The upper Benue catchment area was extracted from the drainage basin/catchment map of Nigeria in ArcView 3.2 environment. The extraction is in form of digitizing and shape-files creation for the catchment area and the river systems in the area. The administrative map of Adamawa state was overlayed on the created upper Benue catchment map to show the areas covered by the study within Adamawa state and the upper Benue catchment area.

The seven (7) bands of the satellite image for 1988 and 2003 were imported into ENVI environment. An ENVI meta-file was created using all the seven bands of the image. The meta-file enables processing and analysis of all the image bands or selected bands concurrently. A subset (sub-map) of the meta-file was created and exported in Geo Tiff format (.tiff). In ILWIS environment, the sub-mapped imageries were enhanced through filtering and stretching procedures. A supervised classification procedure using selected training samples was adopted and the image was classified into 6 classes namely; vegetation, Water body, sand/dried up water body, rock-outcrop/highland, built up area, and bare land.

The Shuttle Radar Topographic Mission (SRTM) image of the Upper Benue Catchment Areas was used to generate contour and elevation maps for the catchment area. The ENVI 4.5 Overlay/Contour Lines operation was used to generate the contour map for the area in ENVI (.evf) format. The contour map was vectorised and exported as shapefile to ArcView environment. Creating the grid map of the using the elevation data, the resulting map was overlayed on the administrative map of the area.

Statistical and graphical methods was used in presenting results for the areal extent of changes in the area and percentage changes in land use pattern. Line and bar charts were used in presentation of the statistical analysis.

\section{Presentation of Results}

Identification and Classification of Land Use/Land cover 


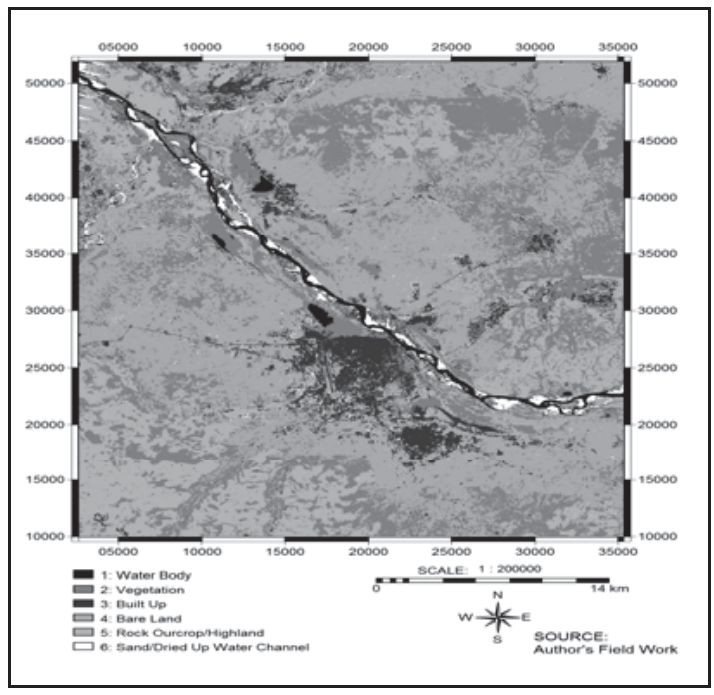

Figure 3: Land use/Land cover Classification of 1988 Landsat ETM Image

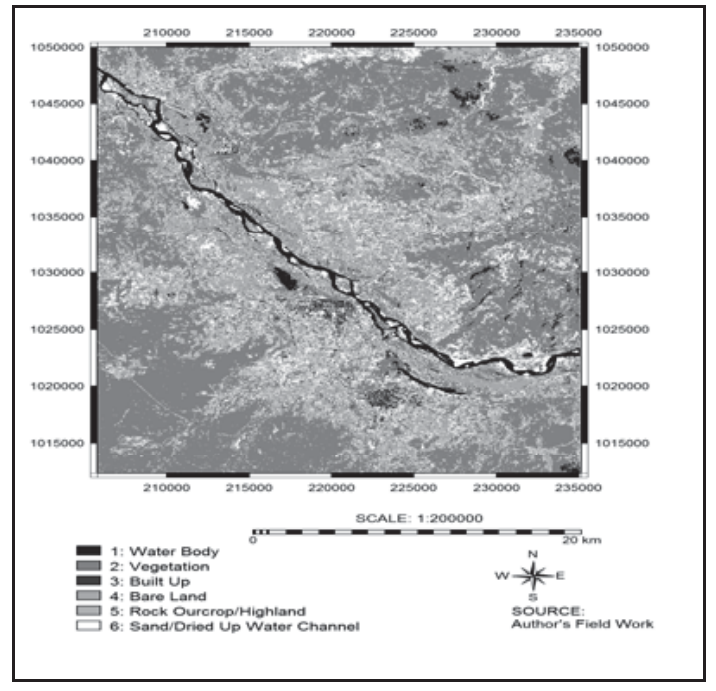

Figure 4: Land use/Land cover Classification of 2003 Landsat ETM Image

Figures 3 and 4 shows the classification result of the landsat ETM image for 1988 and 2003 respectively. Six (6) classes - water body, vegetation, built up, bare land, rock-outcrop and sand/dried up water channel was used in the analysis. The results shows an enormous changes in land cover pattern between 1988 and 2003 in the area. Majority of the large vegetation cover present in the area in 1988 were observed to be absent in 2003. It was also observed that areas that are formally vegetal covered have been replaced by rockoutcrop, highland or bare land. This significantly indicate a large expanse of vegetal cover have been lost between 1988 and 2003 in the area, and the land surface and rocks are exposed, thus resulting in larger area of bare lands and rock outcrops in 2003.

Figures 5 and 6, describes the statistics of the classification showing the spatial pattern and areal extent of in land cover/land use in the area for 1988 and 2003. Figure 5 shows that a total area of 39,896,907 square metres were covered by water body in $1988,892,876,371$ sq.mtr by vegetation, $27,168,950$ by built up areas, 263,908,959 by bare land, 23,237,660 by rock outcrop/highland, and 13,328,210 by sand/dried up water bodies. Figure 6 reveals that 17,237,700 square metres were covered by water bodies, 423,482,400 by vegetation, $111,807,000$ by built up area, $596,305,800$ by bare land, 348,200,100 by rock outcrop/highland, and 23,445,000 square metres are covered by sands or are water channels that have dried up.

The changes in land cover/land use between 1988 and 2003 is presented in Table 1. The table shows the total area covered by each features in hectares and their respective proportions (in percentage). The table also reveals the percentage of changes of land cover types that occurs in the area between the given periods. A negative percentage change indicate loss of land cover/land use type. From the table, between 1988 and 2003, 39.66\% of water body and $35.66 \%$ of vegetal cover were lost in the area. Built up areas increased by $60.99 \%$, bare land by $38.64 \%$, rock-outcrop by $87.49 \%$, and sands/water bodies that have dried up by $27.51 \%$. 
Spatial pattern and areal extent of land cover/land use

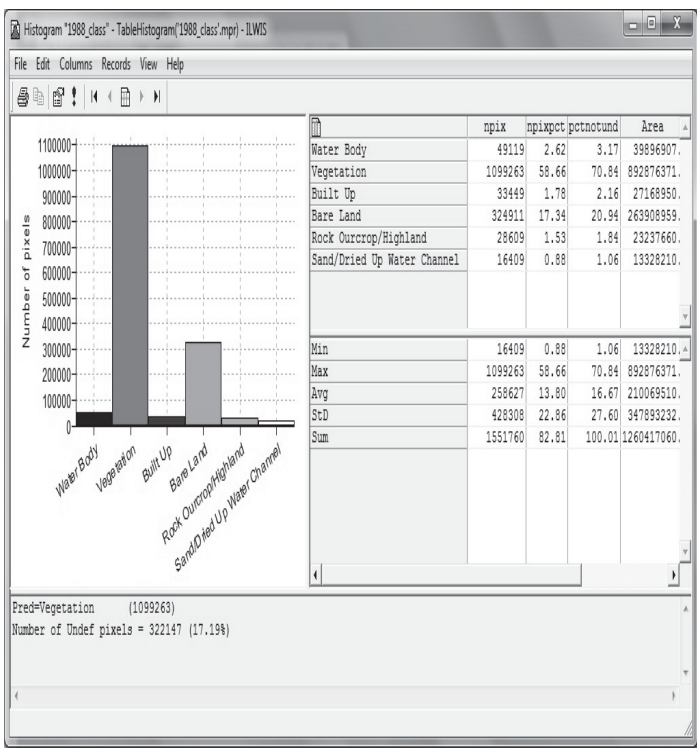

Figure 5: Spatial pattern and areal extent of land cover/land use in 1988

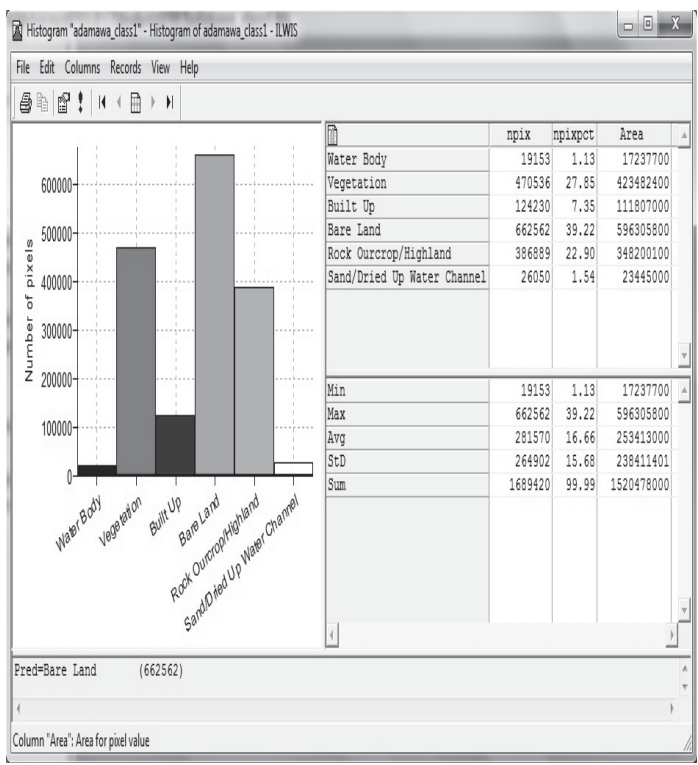

Figure 6: Spatial pattern and areal extent of land cover/land use in 2003

Changes in land cover/land use pattern between 1988 and 2003

\begin{tabular}{|c|c|c|c|c|c|c|}
\hline \multirow[t]{2}{*}{ FEATURES } & \multicolumn{2}{|c|}{ TOTAL AREA(Ha) } & \multicolumn{2}{|c|}{ TOTAL AREA (\%) } & \multirow{2}{*}{$\begin{array}{c}\text { CHANGE } \\
(\%)\end{array}$} & \multirow{2}{*}{ YEARS } \\
\hline & 1988 & 2003 & 1988 & 2003 & & \\
\hline Water Body & $3,989.69$ & $1,723.77$ & 69.83 & 30.17 & -39.66 & 15 \\
\hline Vegetation & $89,287.64$ & $42,348.24$ & 67.83 & 32.17 & -35.66 & 15 \\
\hline Built Up & $2,716.90$ & $11,180.70$ & 19.55 & 80.45 & 60.90 & 15 \\
\hline Bare Land & $26,390.90$ & $59,630.58$ & 30.68 & 69.32 & 38.64 & 15 \\
\hline Rock Outcrop/Highland & $2,323.77$ & $34,820.01$ & 6.26 & 93.74 & 87.49 & 15 \\
\hline $\begin{array}{l}\text { Sand/Dried Up Water } \\
\text { Channel }\end{array}$ & $1,332.82$ & $2,344.50$ & 36.24 & 63.76 & 27.51 & 15 \\
\hline
\end{tabular}

Table 1: Changes in Land cover/land use pattern between 1988 and 2003 

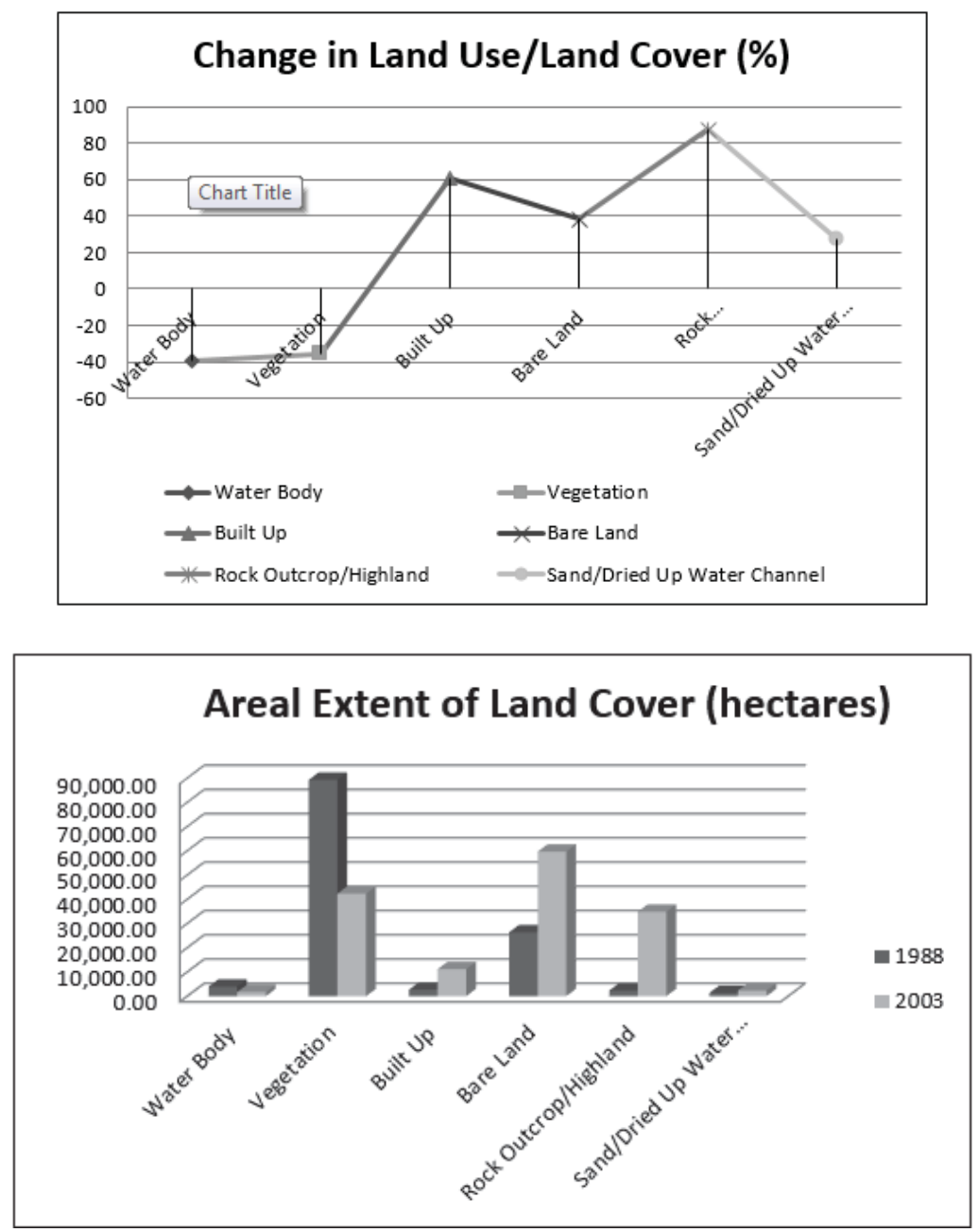

Figure 8: Areal extent of land cover in hectares

Figure 7 indicate that water bodies and vegetal cover has a negative change between 1988 and 2003. That is, large proportion of water bodies and vegetation were lost within the 15 years period covered by the study. It was also observed that the areas covered by built up areas and bare land increased, while rockoutcrops/highlands were exposed and large areas that used to be water channels/body dried up.

The areal extent of land cover in the area is illustrated in figure 8. In 1988, the area is covered mostly by vegetation while in 2003, bare lands is the dominant land cover in the area.

Terrain Analysis 


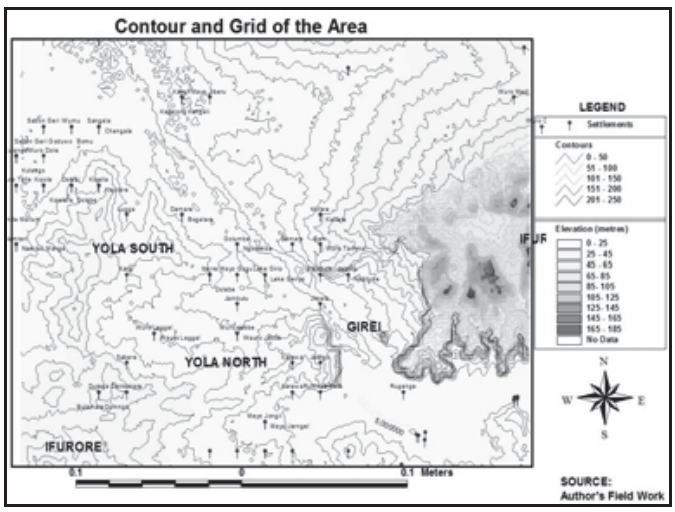

Figure 9: Grid (elevation) and contour map of the area

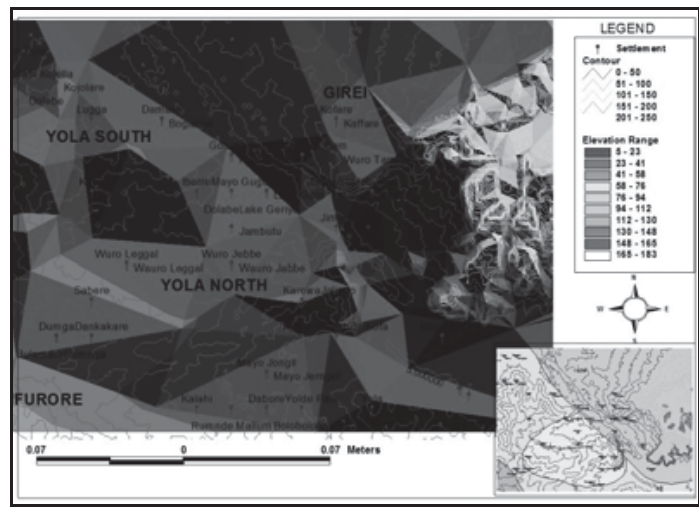

Figure 10: Digital Elevation Model (DEM) of the area

Figures 9 and 10 describe the terrain of the area covered by the study in Adamawa state. Figure 9 presented the contour and Grid (elevation) maps overlayed on the administrative map. The elevation of the area ranges between 0metres to 250metres above the sea level. The highest point in the area is at the eastern part Girei, and southern region of Ifurore local government area. High and wide mountain ranges are concentrated in this area. The elevation of the highest point the area is about 247 metres above the sea level. Lowest point is between 5 metres to 25 metres (Figure 10). These areas are located at the centre of the map, along the River Benue channel.

\section{Implication of the Spatial Pattern of Land Cover/Land Use Change in Adamawa State}

Land use and land cover have changed significantly in the area between 1988 and 2003. This has been attributed to increased human activities in the area. The natural environment have been altered over the 15 years period. Water bodies have reduced in size and volume and some have dried up. Mass of vegetal cover have disappeared while bare land and rocky surfaces were exposed. The noticeable implications of these changes are as follows;

\section{Socio-economic activities}

The result of the study revealed that there is an on-going urbanization processes in the region due to the observed increase in built up areas by $60.9 \%$. This is an indication of increased in human activities and population in the region. Hence, socio-economic activities have significantly increased in the area between 1988 and 2003, particularly in Yola North and Yola South. Creation of the Adamawa state with its Capital at Yola in 1991 is a potent factor responsible for the accelerated urbanization observed in the area.

\section{Shortage of water and prevalence of drought conditions}

Water bodies was observed to have reduced by $39.66 \%$ in the region over a period of 15 years while sand and water bodies that dried up increased by $27.51 \%$. This is a significant indication of drought in the region. Many part of the region, particularly areas farther away from the Benue channel would not have access to portable and save water for domestic consumption. This would consequentially have effect on the health and productivity level of the inhabitants of the region. 


\section{Food shortage}

The region lies in the Sudan Savannah belt of Nigeria, it depends solely on irrigation agriculture to meet its food needs due to inadequate rainfall. With the rate of vegetation loss cum water bodies reduction in the area, water accessibility for irrigation would be a challenge. As a result of reduction in vegetal cover, land moisture and nutrient contents to support sustainable cultivation would be drained due to persistent exposure of the land surface to heat. Consequentially, there would be shortage of food and increase in prices of food commodities.

\section{Desertification}

With the observed land use/land cover change in the area, the region has high tendencies and vulnerability towards desertification. A continuous and unchecked reduction in water quantity, loss of vegetal cover, and increasing exposure of the land surface are potent factors responsible to rapid desertification.

\section{Increase in temperature}

Vegetal cover absorbs solar radiation and recharges the atmosphere, hence it regulates the temperature of an area. Water bodies and soil moisture also absorbs temperature in the same manner. However, with the current trends in land cover pattern and changes in the Adamawa region - exposed land and rock surfaces at the expense of vegetal cover and water bodies, there would be increase in temperature of the area and a consequential potential of an urban heat island. Loss of energy, hence productivity would be an effect of high temperature on the inhabitants of the region if the current land cover change persists.

\section{Paralyzed inland water transportation}

Reduction in water bodies with large part the river channel filled with sands is an impediment to sustainable water transportation, particularly along the river Benue channel. Overfilled of the river channel with sand and reduction of the water volume to levels where rocks are exposed makes most of the rivers not suitable for navigation. Hence, there would be loss of jobs for the ferry and canoe transporters in the area, and the usual movement of people who depend on transportation by water would be impaired.

\section{Conclusion}

Changes in land cover and land use pattern has received high and persistent attention over the years particularly in developing countries. The need for urban and infrastructural developments in these regions has necessitated rapid modification of the natural environment. The consequences of these modifications, especially where there are no adequate planning and management practices, have become threats to the sustainability of the natural environment. The hinterland have been the major focus of urbanization over the years, however, many emerging big cities have developed around road networks/intercession or along the coast/river channel. The inescapable fact is that, the imminent challenges of human development at the expense of the natural environment persist in all areas where there is no adequate planning and management practices regardless of the location of the area

The consequences of unplanned human development would be severe compared to its intended benefits. Congestion, shortage of food, high cost of living, rapid desertification, drought, increase temperature, and increased crime are some of the adverse effect of unplanned urban development. Arable 
farmlands and rich biodiversity have been wiped away, water quality and quantity reduced, and soil conditions have deteriorated.

City planners, government agencies, and concerned institutions charged with the responsibilities of urban and environmental planning and management have not been actively involved. Poor educational qualification, inadequate experience, and lack of knowledge of remote sensing and Geo-Information technology are impediments to the productivity of city planners and environmental managers. The inability of planners to forecast and plan beyond the present human needs has been responsible for diverse environmental and human problems arising as a result of developmental processes in many developing countries.

This study utilizes remote sensing and geo-information technology in the analysis of land cover/land use pattern along the River Benue channel in Adamawa state between 1988 and 2003. Land cover/land use has changed dramatically over the past 15 years. Pattern of the changes have been adverse on the natural environment of the area. Hence, there is need for a balance between human development, land use planning, and water resource management to ensure a sustainable development in the region. If the current trends of unplanned urban development at the expense of the natural environment continues, and no active response to the deteriorating pattern of land cover and environmental changes is initiated, the effects would be greater than the intending benefits of the development. However, various measures could be consider in an attempt to reverse the effects of poor land use planning on the environment, to prevent future impacts of unplanned urbanization, and to curtail uncontrolled land cover changes. The following recommendations are therefore suggested;

1. Shelterbelts should be developed in areas with trait of desertification and tree planting should be considered as part of all developmental projects.

2. A stable river channelization and dredging policy should be implemented whereby flow of water in the rivers would be improved by removing sands and rock particles in the channels. This would facilitate inland water transportation system.

3. Adequate planning should be put in place by the government or its agencies for a planned and organized irrigation agriculture system in these regions.

4. Urban planners in implementing various urban development projects should consider projective planning mechanisms. That is, consideration for a long-term effect of any developmental project on both human and the natural environment.

5. Both urban planners and environmental managers should work together in the implementation of developmental policies and execution of projects.

6. Use of remote sensing and geographic information system should be encouraged by urban planners and environmental managers in planning, management, and in making various developmental decisions.

\section{References}

Ajanuga A. G. and Ekwoanya M. A.: Temporal Changes in Land Use Pattern in the Benue River Floodplain and Adjoining Uplands at Makurdi, Nigeria. University of Agriculture, Makurdi, Nigeria.

Eludoyin A.O., Akinbode O. M. , and O.A. Ediang: Challenges of River Basin Information System (RBIS) as a Framework For the Assessment and Monitoring of Surface Water in Nigeria. International Symposium on New Directions in Urban Water Management. 12-14 September 2007, UNESCO Paris

Ikusemoran M (2009): Assessment Of Human Impacts On Landuse And Vegetation Cover Changes In Mubi Region, Adamawa State, Nigeria; Remote Sensing And Gis Approach. Global Journal of Environmental Sciences 8(2), pp112, April 2009. ) Bachudo Sciences Co. Ltd., Nigeria. ISSN 1596 - 6194.

Ikusemoran M (2009): Landuse And Landcover Change Detection In The Kainji Lake Basin Nigeria Using Remote Sensing And GIS Approach. Bayero Journal of Pure and Applied Sciences, 2(1): 83-90, Feb 2009. 
Ishaq S. E., Agada P. O. and Rufus S. (2012): Spatial and Temporal Variation in Water Quality of River Benue, Nigeria. Journal of Environmental Protection, July 2012, 3, 915-921.

Maitera O. N., Ogugbuaja V. O., and Barminas J. T. (2011): Determination Of Trace Metal Levels In Water And Sediments Of River Benue In Adamawa State, Nigeria. Journal of Ecology and the Natural Environment Vol. 3(4), pp. 149-156, April 2011. Available online at http://www.academicjournals.org/jene

Ortserga D. S. (2012): Towards A Model Explaining Change In Agricultural Land Use Patterns In Ute Districts Of Vandeikya Local Government Area, Benue State, Nigeria. International Journal of Humanities and Social Science 2(4) Feb 2012. Centre for Promoting Ideas, USA.

Oyinloye M.A. and Kufoniyi O., (2011): Analysis of Land Use, Land cover, and Urban Expansion in Akure, Nigeria. Journal of Innovative Research in Engineering and Sciences 2(4), (234 - 248) June 2011. ISSN 2141-8225. Global Research Publishing, 2011 
